\title{
MANAJEMEN PEMBELAJARAN PENDIDIKAN KARAKTER DI SD KREATIF KECAMATAN KARANGAN KABUPATEN TRENGGALEK
}

\author{
Eries Norma Yusmita \\ eriesnorma@gmail.com \\ Pendidikan Guru Sekolah Dasar \\ STKIP PGRI Tulungagung
}

\begin{abstract}
This study aims to provide an overview of the implementation of character education in elementary school of Kreatif, Karangan district, Trenggalek. Approach that used in this research is qualitative approach and this research type is a case study. This research is focused on the case of planning, implementation, evaluation, and obstacles of character education implementation in elementary school of Kreatif. The character education that is planned and implemented by elementary school of Kreatif is 3, that is the education of the character of discipline, honesty, and religious. Character education applied in elementary school of Kreatif not only carried out in the learning process but also implemented outside the learning process. Educators do not just ask their students to train and instill character education in themselves. Educators also set an example of appropriate behavior with character education that has been planned and applied to elementary school of Kreatif.
\end{abstract}

Keywords: character education, elementary school.

\begin{abstract}
Abstrak: Penelitian ini bertujuan untuk memberikan gambaran pelaksanaan pendidikan karakter di SD Kreatif kecamatan Karangan kabupaten Trenggalek. Pendekatan yang yang digunakan penelitian ini pendekatan kualitatif dan Jenis penelitian ini adalah studi kasus. Penelitian ini difokuskan pada kasus perencanaan, pelaksanaan, evaluasi, dan hambatan pelaksanaan pendidikan karakter di SD Kreatif. Pendidikan karakter yang direncanakan dan diterapkan oleh SD Kreatif ada 3, yaitu pendidikan karakter kedisiplinan, kejujuran, dan religius. Pendidikan karakter yang diterapkan di SD Kreatif tidak hanya dilaksanakan dalam proses pembelajaran, melainkan juga dilaksanakan diluar proses pembelajaran. Pendidik tidak hanya meminta peserta didiknya untuk melatih dan menanamkan pendidikan karakter dalam dirinya. Pendidik juga memberi contoh perilaku yang sesuai dengan pendidikan karakter yang telah direncanakan dan diterapkan pada SD Kreatif.
\end{abstract}

Kata kunci: pendidikan karakter, sekolah dasar

\section{PENDAHULUAN}

Gagalnya pendidikan pada jenjang sekolah dasar terutama dalam pembinaan karakter diyakini akan berdampak sistemik terhadap pendidikan berikutnya. Mendiknas (2010: 1) menyebutkan bahwa:

"Pada jenjang sekolah dasar ini porsinya mencapai $60 \%$ dibandingkan dengan jenjang pendidikan lainnya. Hal ini agar lebih mudah diajarkan 
Eries, Manajemen Pembelajaran Pendidikan Karakter...

dan melekat di jiwa anak-anak itu hingga kelak ia dewasa. Pembinaan karakter yang termudah dilakukan adalah ketika anak-anak masih duduk di bangku SD. Itulah sebabnya kita memprioritaskan pendidikan karakter di tingkat SD. Bukan berarti pada jenjang pendidikan lainnya tidak mendapat perhatian namun porsinya saja yang berbeda."

Berdasarkan pengalaman yang terjadi saat ini, banyak ditemui masalah moral yang terdapat dalam diri peserta didik sekolah dasar. Hal ini ditandai dengan perilaku peserta didik yang suka terlambat masuk sekolah maupun masuk ke kelas setelah jam istirahat, menyontek, bersikap kasar kepada teman, berkelahi, mengolok-olok teman, corat-coret bangku sekolah, tidak menjaga kebersihan KM/WC sekolah, merusak fasilitas sekolah seperti taman dan perpustakaan, membeda-bedakan teman, tidak mengenakan seragam sekolah sesuai dengan ketentuan, membuang sampah di sembarang tempat, tidak sopan kepada guru. Menurut Akbar (2011: 1-2) Praktik pembelajaran nilai dan karakter di SD kurang sesuai teori pembelajaran nilai dan karakter secara benar, kultur sekolah kurang kondusif untuk pendidikan nilai dan karakter, dan adanya perilaku anak-anak SD yang kurang baik. Persoalan di atas terjadi karena praktik pendidikan yang cenderung overkognitive dan cenderung mengabaikan aspek konasi (willingness), akibatnya banyak peserta didik yang berpengetahuan cukup banyak tetapi mereka kurang mau melakukan apa yang dia ketahuai karena aspek konasinya kurang terbangun dengan baik.

Berdasarkan data yang diperoleh tersebut, peneliti tertarik untuk mengadakan penelitian yang berkaitan dengan pelaksanaan pendidikan karakter yang dilakukan di jenjang pendidikan sekolah dasar. Penelitian ini berjudul "Manajemen Pembelajaran Pendidikan Karakter SD Kreatif Kecamatan Karangan Kabupaten Trenggalek".

Alasan peneliti memilih SD Kreatif karena SD ini merupakan SD yang baru berdiri tetapi sudah menjadi favorit di Kecamatan Karangan yang melaksanakan pendidikan karakter. Hal ini dapat dilihat dari perkembangan penerimaan peserta didik setiap tahunnya dan hasil observasi yang dilakukan peneliti terhadap pelaksanaan kegiatan sehari-hari siswa SD Kreatif telah melaksanakan kegiatan yang berkaitan dengan karakter dan juga pada dokumen kegiatan pembelajaran mencantumkan karakter-karakter yang ingin dikembangkan serta dengan jelas dijabarkan tentang rencana-rencana sekolah yang akan dilakukan. Selain itu juga penataan fisik sekolah yang syarat akan nilai dan nyaman ditempati peserta didik, fasilitas yang cukup baik, yakni berupa laboratorium komputer, perpustakaan dengan koleksi buku yang lengkap, mushola, dan lain-lain. Tenaga pendidik yang berada di SD Kreatif 90\% memiliki gelar Strata 1. Selain itu peserta didik SD Kreatif juga memiliki prestasi yang membanggakan baik di tingkat kecamatan dan kabupaten.

Sebagaimana yang terdapat dalam Buku Induk Kebijakan Nasional Pembangunan Karakter Bangsa 2010-2025 (dalam Puskurbuk, 2011: 1-2) : 
Eries, Manajemen Pembelajaran Pendidikan Karakter...

"Pembangunan karakter yang merupakan upaya perwujudan amanat Pancasila dan Pembukaan UUD 1945 dilatarbelakangi oleh realita permasalahan kebangsaan yang berkembang saat ini, seperti: disorientasi dan belum dihayatinya nilai-nilai Pancasila; keterbatasan perangkat kebijakan terpadu dalam mewujudkan nilai-nilai Pancasila; bergesernya nilai etika dalam kehidupan berbangsa dan bernegara; memudarnya kesadaran terhadap nilai-nilai budaya bangsa; ancaman disintegrasi bangsa; dan melemahnya kemandirian bangsa".

Manajemen pembelajaran merupakan pengelolaan kegiatan belajar mengajar yang dilakukan secara sistematis dengan berpatokan pada peraturan untuk peningkatan kualitas kehidupan masyarakat dan bangsa di masa mendatang yang di dalamnya terdapat pendidikan nilai, pendidikan budi pekerti, pendidikan moral, dan pendidikan watak untuk mengembangkan kemampuan peserta didik Pendidikan karakter merupakan upaya-upaya yang dirancang dan dilaksanakan secara sistematis untuk membantu peserta didik memahami nilai-nilai perilaku manusia yang berhubungan dengan Tuhan Yang Maha Esa, diri sendiri, sesama manusia, lingkungan, dan kebangsaan yang terwujud dalam pikiran, sikap, perasaan, perkataan, dan perbuatan berdasarkan norma-norma agama, hukum, tata karma, budaya, dan adat istiadat. Menurut Lickona, (dalam Akbar, 2011) Character consist of operative value, value in action. Untuk membangun watak baik, perlu pengembangan-pengembangan secara seimbang antara knowing the good, desiring the good, dan doing the good. Pendidikan karakter dikatakan berhasil jika terjadi keseimbangan antara pengetahuan tentang karakter baik, merasakan karakter baik, dan melakukan karakter baik.

Tujuan pendidikan karakter adalah mengembangkan karakter manusia yakni akhlak yang mulia tidak hanya di dalam lingkungan sekolah namun juga di lingkungan keluarga maupun masyarakat dengan proses pendidikan yang melibatkan aspek kognitif, afektif, dan psikomotor sehingga akhlak mulia tersebut sesuai dengan Pancasila dan UUD 1945. Hal ini sesuai dengan Puskurbuk (2011: 2) pendidikan karakter pada intinya bertujuan membentuk bangsa yang tangguh, kompetitif, berakhlak mulia, bermoral, bertoleran, bergotong royong, berjiwa patriotik, berkembang dinamis, berorientasi ilmu pengetahuan dan teknologi yang semuanya dijiwai oleh iman dan takwa kepada Tuhan yang Maha Esa berdasarkan Pancasila. Munir (dalam Akbar, 2010:8) menyebutnya pendidikan karakter bertujuan untuk menumbuhkan karakter positif (memperkuat karakter baik dan memperlemah karakter buruk). Karakter baik adalah karakter yang dikendalikan oleh nilai-nilai kebaikan yang diyakini, dengan keyakinan itulah peserta didik akan bertutur kata, bersikap, berbuat, dan berperilaku baik.

Pada pelaksanaan pendidikan karakter terdapat prinsip-prinsip yang mencerminkan pelaksanaan dari pendidikan karakter itu sendiri. Prinsip-prinsip yang digunakan dalam pengembangan pendidikan karakter dalam Puskurbuk (2010: 11-12) yaitu (1) Berkelanjutan, (2)Melalui semua mata pelajaran, pengembangan diri, dan budaya sekolah, (3) Nilai tidak diajarkan tapi dikembangkan, mengandung makna 
Eries, Manajemen Pembelajaran Pendidikan Karakter...

bahwa, dan (4) Proses pendidikan dilakukan peserta didik secara aktif dan menyenangkan. Berdasarkan prinsip-prinsip yang telah tercantum, pelaksanaan pendidikan karakter dilakukan melalaui dua tahapan kegiatan yaitu pra pelaksanaan dan tahap pelaksanaan pendidikan karakter itu sendiri.

Pada saat tahap pelaksanaan pendidikan karakter yag dilakukan pada saat (1) kegiatan pembelajaran Kegiatan pembelajaran dalam kerangka pengembangan karakter peserta didik dapat menggunakan pendekatan kontekstual sebagai konsep belajar dan mengajar yang membantu guru dan peserta didik mengaitkan antara materi yang diajarkan dengan situasi dunia nyata, sehingga peserta didik mampu untuk membuat hubungan antara pengetahuan yang dimilikinya dengan penerapannya dalam kehidupan mereka. Selain itu pembelajaran dapat dilakukan dengan menggunakan pendekatan kontekstual. Aqip (2011: 53-56), menyebutkan bahwa prinsip-prinsip pembelajaran kontekstual adalah: (a) Konstruktivisme, adalah teori belajar yang menyatakan bahwa peserta didik menyusun atau membangun pemahaman mereka dari pengalamanpengalaman baru berdasarkan pengetahuan awal dan kepercayaan mereka; (b) Bertanya (Questioning), merupakan cara untuk menuntun berfikir peserta didik lebih baik daripada memberi inforfasi untuk memperdalam pemahaman (menganggap siswa sebagai botol kosong), dengan questioning peserta didik dapat mengajukan pertanyaan, belajar menyusun pertanyaan, belajar untuk saling bertanya berdasarkan bukti, dan penjelasan; (c) Inkuiri, adalah proses perpindahan dari pengamatan menjadi pemahaman, di mana pengamatan diawali dengan pertanyaan yang muncul; (d) Masyarakat belajar (Learning Community), adalah sekelompok peserta didik yang terikat dalam kegiatan belajar agar terjadi proses belajar lebih dalam, di mana setiap peserta didik harus mempunyai kesempatan berbicara, berbagi ide, bekerjasama, mendengarkan dan menerima pendapat orang lain dengan cermat, percaya diri dalam berpendapat berdasarkan fakta; (e) Pemodelan (Modelling), adalah proses penampilan suatu contoh agar orang lain berfikir, bekerja, dan belajar. Model dapat diperankan oleh pendidik maupun peserta didik; (f) Refleksi (Reflection), merupakan saat di mana peserta didik menelaah suatu kejadian, kegiatan, dan pengalaman, serta berfikir tentang apa yang dipelajari, merasakan, dan bagaimana peserta didik menggunakan pengetahuan baru; (g) Penilaian autentik (Authentic Assessment), (2) pengembangan budaya sekolah dan pusat kegiatan belajar, kegiatan ini dilakukan pada saat kegiatan rutin, kegiatan spontan, keteladanan, dan pengkondisian keterlaksanaan pendidikan karakter, (3) kegiatan ko-kurikuler atau kegiatan ekstrakurikuler, dan (4) kegiatan keseharian di rumah dan di masyarakat.

Menurut Akbar, (2011: 259) menuliskan bahwa evalusi merupakan proses mendeskripsikan, mengumpulkan, menyajikan, suatu informasi yang bermanfaat untuk pertimbangan dalam pengambilan keputusan. Di dalam evaluasi terdapat kegiatan pengukuran dan penilaian. Untuk mengukur tingkat keberhasilan pelaksanaan pendidikan karakter di satuan pendidikan dalam Puskurbuk (2011: 10) dapat dilakukan 
Eries, Manajemen Pembelajaran Pendidikan Karakter...

melalui berbagai program penilaian dengan membandingkan kondisi awal dengan pencapaian dalam waktu tertentu. Evaluasi keberhasilan tersebut dilakukan melalui langkah-langkah berikut, (1) Menetapkan indikator dari nilai-nilai yang ditetapkan atau disepakati, (2) Menyusun berbagai instrumen penilaian, (3) Melakukan pencatatan terhadap pencapaian indicator, (4) Melakukan analisis dan evaluasi, dan (5) Melakukan tindak lanjut untuk menyempurnakan program. Dalam Puskurbuk (2010: 23) menyatakan bahwa ada dua jenis indikator yang digunakan dalam evaluasi pendidikan karakter. Pertama, indikator untuk sekolah dan kelas. Kedua, untuk mata pelajaran. Indikator sekolah dan kelas adalah penanda yang digunakan oleh kepala sekolah , guru, dan personalia sekolah dalam merencanakan, melaksanakan, dan mengevaluasi sekolah sebagai lembaga pelaksana pendidikan karakter. Indikator ini berkenaan juga dengan kegiatan sekolah yang diprogramkan dan kegiatan sekolah sehari-hari (rutin). Indikator mata pelajaran menggambarkan perilaku afektif seorang peserta didik berkenaan dengan mata pelajaran.

\section{METODE}

Pendekatan yang yang digunakan penelitian ini pendekatan kualitatif. Penelitian ini digunakan untuk mendeskripsikan peristiwa-peristiwa di lapangan sehingga penelitian kualitatif ini bersifat deskriptif. Karakteristik penelitian kualitatif menurut Bogdan and Biklen (dalam Sugiyono 2007:9) adalah sebagai berikut: (1) dilakukan pada kondisi yang alamiah, langsung ke sumber data dan peneliti adalah instrument kunci , (2) penelitian kualitatif lebih bersifat deskriptif. Data yang terkumpul berbentuk katakata atau gambar, sehingga tidak menekankan pada angka, (3) penelitian kualitatif lebih menekankan pada proses daripada produk atau outcome, (4) penelitian kualitatif melakukan analisis data secara induktif, (5) penelitian kualitatif lebih menekankan makna (data dibalik yang teramati). Penggunaan pendekatan kualitatif dalam penelitian ini dimaksudkan agar peneliti dapat mengetahui serta mendeskripsikan secara jelas dan rinci tentang pelaksanaan pendidikan karakter di SD Kreatif. Dalam pelaksanaan penelitian ini peneliti tidak merubah place (tempat), activity (kegiatan), actor (orang) dan data disajikan dalam bentuk kata-kata yang diuraikan dari dokumen pribadi, catatan lapangan, ucapan dan tindakan responden, dokumen sekolah, dan lain-lain.

Jenis penelitian ini adalah studi kasus. Menurut Sukmadinata (dalam Yuniarti , 2011:22) penelitian kualitatif yang berjenis studi kasus merupakan penelitian yang difokuskan pada satu fenomena saja yang dipilih dan ingin dipahami secara mendalam, dengan mengabaikan fenomena-fenomena lainnya. Penelitian ini difokuskan pada kasus perencanaan, pelaksanaan, evaluasi, dan hambatan pelaksanaan pendidikan karakter di SD Kreatif.

\section{Lokasi Penelitian}

Penelitian ini mengambil lokasi penelitian di SD Kreatif di Kecamatan Karangan Kabupaten Trenggalek. SD Kretaif ini merupakan SD yang baru berdiri tetapi sudah 
Eries, Manajemen Pembelajaran Pendidikan Karakter...

menjadi favorit di Kecamatan Karangan yang melaksanakan pendidikan karakter. Hal ini dapat dilihat dari perkembangan penerimaan peserta didik setiap tahunnya. Selain itu peserta didik SD Kreatif juga memiliki prestasi yang membanggakan baik di tingkat kecamatan dan kabupaten.

\section{Sumber Data}

Sumber data dalam penelitian ini adalah berupa situasi alamiah, wajar (tanpa rekayasa) dimana data tersebut digantikan dalam bentuk foto, catatan lapangan, hasil wawancara baik dari kepala sekolah, tenaga pendidik, peserta didik, maupun wali peserta didik, rekaman video (saat pembelajaran di kelas, di luar kelas, kegiatan lain yang dilakukan tenaga pendidik, peserta didik, kepala sekolah, dan lain sebagainya), dokumen resmi maupun pribadi dari pihak sekolah. Jenis data yang diperlukan dalam penelitian ini adalah data yang berkaitan dengan pelaksanaan pendidikan karakter yang ada di SD Kreatif, antara lain seperti wawancara tentang rencana pelaksanaan pendidikan karakter, kurikulum KTSP, silabus, RPP, pelaksanaan pembelajaran, pelaksanaan pembiasaan, ekstrakulikuler maupun pelaksanaan penilaian pendidikan karakter yang dilakukan pendidik kepada peserta didik.

\section{Teknik Pengumpulan Data}

Menurut Wiyono (dalam Yuniarti, 2011:25) teknik pengumpulam data dalam penelitian kualitatif, yaitu wawancara mendalam, pengamatan partisipasi (participation observation), dan analisis dokumen. Berikut akan dipaparkan teknik-teknik pengumpulan data yang dilakukan oleh peneliti yaitu.

\section{Wawancara Mendalam}

Menurut Mc Millan dan Schumacher (dalam Satori, 2010:130) wawancara mendalam adalah tanya jawab yang terbuka untuk memperoleh data tentang maksud hati partisipan (peneliti) - bagaimana menggambarkan dunia mereka dan bagaimana mereka menjelaskan atau menyatakan perasaannya tentang kejadian-kejadian penting dalam hidupnya. Jadi melalui wawancara peneliti dapat mengetahui hal-hal yang lebih mendalam tentang informan dalam menginterprestasikan situasi dan fenomena yang terjadi dimana hal ini tidak dapat ditemukan melalui observasi.

Peneliti menggunakan jenis wawancara tak berstruktur dalam penelitian ini. Menurut Sugiyono (2007: 74) wawancara tidak terstruktur adalah wawancara yang bebas di mana peneliti tidak menggunakan pedoman wawancara yang telah tersusun secara sistematis dan lengkap untuk pengumpulan datanya. Pedoman wawancara yang digunakan hanya berupa garis-garis besar permasalahan yang akan ditanyakan. Wawancara tidak terstruktur digunakan peneliti untuk memperoleh data sebagaimana sesuai dengan rumusan masalah. Pokok-pokok pertanyaan wawancara nantinya akan dikembangkan saat wawancara berlangsung. Alat yang digunakan untuk wawancara adalah buku cataan, dan camera dengan tujuan untuk meningkatkan keabsahan penelitian. 
Eries, Manajemen Pembelajaran Pendidikan Karakter...

\section{Observasi}

Observasi adalah langkah pertama yang dilakukan peneliti dalam melakukan penelitian. Observasi yang dilakukan peneliti dalam penelitian ini adalah observasi partisipatif. Menurut Stainback (dalam Sugiyono, 2007: 65) dalam observasi partisipatif peneliti mengamati apa yang dikerjakan orang, mendengarkan apa yang mereka ucapkan, dan berpartisipasi dalam aktivitas mereka. Jenis observasi partisipatif yang digunakan peneliti adalah partisipasi pasif, jadi dalam hal ini peneliti datang di tempat kegiatan orang yang diamati, tetapi tidak ikut terlibat dalam kegiatan tersebut.

Hal yang observasi oleh peneliti adalah sesuai dengan rumusan masalah yang diajukan, yakni tentang persiapan pelaksanaan, pelaksanaan, evaluasi, dan hambatan pendidikan karakter yang berlangsung di SD Kreatif. Objek yang diobsevasi adalah kegiatan pendidik dan peserta didik mulai sekolah dibuka hingga ditutup baik yang dilaksanakan di luar kelas maupun di dalam kelas, kegiatan pembelajaran yang berlangsung baik di dalam kelas maupun luar kelas, serta lingkungan sekolah maupun lingkungan kelas. Untuk memperolah data, peneliti menggunakan pedoman observasi objek penelitian serta catatan lapangan.

\section{Analisis Dokumen}

Menurut Wiyono (dalam Yuniarti, 2011: 27) ada beberapa jenis bahan dokumentasi antara lain dokumen yang berupa tulisan pribadi, dokumen resmi, foto ataupun bahan statistik. Dokumen yang berupa foto dapat digunakan sebagai kunci untuk mendeskripsikan suatu kejadian yang sedang berlangsung pada saat foto itu diambil, yang tentu relevan dengan masalah yang diambil.Dokumen yang diambil saat penelitian berlangsung adalah dokumen yang sesuai dengan rumusan masalah, yaitu tentang perencanaan pelaksanaan pendidikan karakter, pelaksanaan pendidikan karakter, dan bagaimana cara mengevaluasi pendidikan karakter yang telah dilaksanakan. Saat penelitian, peneliti menghimpun dokumen yang berupa catatan pribadi, dokumen resmi milik sekolah, foto dan rekaman. Teknik dokumentasi ini digunakan oleh peneliti adalah untuk mendapatkan informasi yang belum di dapatkan dengan teknik pengumpulan data melalui wawancara maupun observasi. Dokumen yang berupa foto dapat digunakan sebagai kunci untuk menjelaskan kejadian yang sedang berlangsung saat proses penelitian yang tentunya sesuai dengan rumusan masalah penelitian

\section{Analisis data}

Menurut Miles dan Huberman (dalam Sugiyono, 2007: 91) menyatakan bahwa aktivitas dalam analisis data kualitatif dilakukan secara interaktif dan berlangsung terus menerus sampai tuntas sehingga datanya sudah jenuh. Aktivitas dalam analisis data tersebut, yaitu data reduction (penyederhanaan data), data display (paparan/sajian data), dan conclusion drawing/verification (penarikan kesimpulan).

Penyederhanaan data yang dilakukan peneliti adalah dengan melakukan pemilihan data baik dari wawancara, observasi, maupun dokumentasi. Data-data 
Eries, Manajemen Pembelajaran Pendidikan Karakter...

tersebut dipilih untuk dikelompokkan sesuai dengan setiap rumusan masalah. Selain itu penyederhanaan data dilakukan untuk mengurangi data-data yang dianggap kurang berfungsi untuk melengkapi hasil penelitian atau tidak sesuai dengan rumusan masalah. Selanjutnya peneliti melakukan pengkodean terhadap setiap data yang telah dikompokkan sesuai rumusan masalah. Kode-kode tersebut antara lain WW (wawancara), OB (observasi), dan DOK digunakan untuk data hasil dokumentasi.

Penyajian data yang dilakukan oleh peneliti adalah dengan menjadikan satu semua informasi yang telah didapat baik data hasil observasi, wawancara, dan dokumentasi untuk rumusan masalah yang pertama dan menarik suatu kesimpulan sementara. Begitu seterusnya untuk rumusan masalah yang lain. Jadi ada beberapa kesimpulan sementara sesuai dengan rumusan masalah.

Setelah menarik kesimpulan sementara untuk masing-masing rumusan masalah penelitian. Selanjutnya peneliti menarik kesimpulan akhir dari setiap rumusan masalah penelitian. Jika setiap rumusan masalah telah mendapatkan kesimpulan akhir, maka kesimpulan-kesimpulan inilah yang dinamakan temuan dalam penelitian, dan isiny

\section{Pengecekan Keabsahan Data}

Keabsahan data merupakan hal terpenting dalam penelitiaan, karena akan menjamin tingkat keterpercayaan temuan dalam pemecahan masalah yang diteliti. Pengecekan keabsahan data ini dilakukan melalaui, (1) perpanjangan kehadiran peneliti, hal ini bertujuan dapat mendapatkan data dan informasi yang lebih lengkap, serta lebih cermat dalam mengamati objek penelitian sehingga diharapkan dapat mengurangi ketidakbenaran informasi yang diperoleh peneliti, (2) ketekunan pengamatan, Dalam hal ini peneliti melakukan pengamatan secara lebih cermat dan berkesinambungan. Dengan melakukan ketekunan pengamatan maka kepastian data dan urutan peristiwa yang berkaitan dengan rumusan masalah dapat direkam secara pasti dan sistematis oleh peneliti, dan (3) melakukan triangulasi, Triangulasi merupakan pemeriksaan data dari berbagai sumber dengan berbagai cara dan berbagai waktu. Ada dua macam triangulasi yang digunakan dalam penelitian ini, yakni triangulasi sumber dan triangulasi teknik. Triangulasi sumber dilakukan dengan cara mengecek data yang telah diperoleh melalui berbagai sumber sesuai dengan masalah yang ada. Triangulasi teknik dilakukan dengan cara mengecek data kepada sumber yang sama dengan teknik yang berbeda. Misalnya, data yang diperoleh dari hasil wawancara kemudian dicek kembali oleh peneliti melalui observasi dan dokumentasi.

\section{PAPARAN DATA DAN PEMBAHASAN}

\section{Perencanaan Pelaksanaan Pendidikan Karakter di SD Kreatif Pendidikan Karakter Kedisiplinan di SD Kreatif}

Guru kelas dalam menanamkan pendidikan karakter kedisiplinan kepada peserta didik memang dituntut untuk selalu kreatif dan inovatif. Guru harus memiliki berbagai macam strategi untuk membentuk sebuah karakter kepada peserta didik. Strategi 
Eries, Manajemen Pembelajaran Pendidikan Karakter...

tersebut dimaksudkan agar dapat menyampaikan visi dan misi dari seorang guru untuk menyampaikan sesuatu dan dapat diterima oleh peserta didik dengan baik. Setiap strategi yang akan dilakukan membutuhkan perencanaan yang baik tentunya harus melihat situasi, kondisi, dan kebutuhan lingkungan sekitar. Tanpa memperhitungkan itu semua, maka sebaik apapun perencanaan yang dibuat, maka akan berakhir dengan siasia. Apabila perencanaan tersebut telah sesuai dengan situas, kondisi dan kebutuhan lingkungan sekitar, maka perencanaan tersebut harus melalui proses musyawarah dari berbagai pihak yang berkepentingan didalamnya yaitu Kepala Sekolah, Guru dan Komite Sekolah.

Dalam perencanaannya, Kepala Sekolah mengajak seluruh Guru dan komite Sekolah untuk duduk bersama membicarakan perencanaan penanaman karakter kedisiplinan di sekolahnya. Tentunya terdapat banyak ide-ide yang muncul dari guru dan komite sekolah. Namun sikap kepala sekolah yang mampu bersikap bijak dalam menentukan keputusan untuk menetapkan indikator dari karakter kedisiplinan yang akan ditanamkan kepada peserta didik sangat baik dengan memperhitungkan kebutuhan peserta didik dalam menyongsong masa depan dan kebutuhan wali murid agar anakanaknya menjadi sosok yang disiplin diberbagai situasi dan kondisi.

Oleh karena itu, kepala sekolah SD Kreatif menetapkan beberapa indikator yang harus ditanamkan kepada peserta didik yaitu : 1) Penanaman karakter kerapian, 2) Penanaman karakter kejujuran, 3) Penanaman karakter tepat waktu, dan 4) penanaman karakter beribadah. Setalah menetapkan beberapa indikator perencanaan tersebut dan disepakati oleh semua pihak yang berkepentingan didalam dunia pendidikan, maka kepala sekolah menyerahkan sepenuhnya pelaksanaan penanaman karakter kedisiplinan kepada guru kelas.

\section{Pendidikan Karakter Kejujuran di SD Kreatif}

Perencanaan yang dilakukan sekolah untuk menanamkan karakter kejujuran kepada peserta didik adalah dengan menggunakan motivasi dan pembiasaan kepada peserta didik. Sikap kejujuran juga merupakan sikap yang penting dalam membentuk kepribadian siswa dalam proses pembelajaran. Pada proses pembelajaran siswa dituntut untuk menunjukkan sikap sebagai seseorang yang dapat dipercaya dalam perkataan dan tindakan tanpa melakukan kecurangan yang bertujuan untuk membentuk siswa yang berprestasi.

Dirasa sangat sulit menanamkan sikap jujur kepada siswa apabila guru tidak memberikan pemahaman yang memadai tentang makna kejujuran.Sebab, selama ini, siswa sekedar mengerti bahwa salah satu ciri orang yang baik adalah bersikap jujur. Sayangnya, ia kurang memahami alasan seseorang harus bersikap jujur, pengaruhnya terhadap berbagai hal, serta cara menumbuhkan sikap jujur dalam kehidupan seharihari.Akibatnya, tema kejujuran berhenti sebatas pemahaman yang dihafalkan, namun tidak sampai pada tahap penghayatan dan pengalaman. 
Eries, Manajemen Pembelajaran Pendidikan Karakter...

Membentuk karakter jujur pada siswa memang tidak bisa dilakukan dengan sekedar menyampaikan materi kepadanya. Pihak sekolah harus menyediakan alat bantu yang dapat mendukung terciptanya iklim kejujuran pada dirinya. Sikap jujur tidak hanya harus dipahami oleh siswa, akan tetapi sikap jujur juga harus dibiasakan di sekolah. Guru harus menyediakan alat bantu yang dapat digunakan sebagai sarana untuk pembiasaan sikap jujur, salah satunya dengan kantin kejujuran. Dengan ini, akan terciptanya iklim kejujuran di lingkungan sekolah sehingga peserta didik dapat terbiasa melakukan sikap jujur dalam kehidupan sehari-hari di sekolah.

Perencanaan sekolah dalam menanamkan pendidikan karakter kejujuran pada peserta didik yaitu dengan membuat program kantin kejujuran yang prosesnya peserta didik dapat mengambil barang apa saja sesuai kebutuhannya dengan meletakkan uang sesuai harga barang yang diambil pada tempat yang telah disediakan oleh guru. Selain itu, terdapat pula proses yang menerapkan piket peserta didik untuk mengambilkan jatah makanan teman-temannya sekelas dengan jatah yang telah diberikan oleh pengelola dapur dan wajib mengembalikan sisa jatah makan temannya apabila terdapat kelebihan.

Selain proses pembiasaan yang diterapkan oleh guru dalam menanamkan pendidikan karakter peserta didiknya, terdapat pula motivasi yang selalu diberikan oleh guru pada saat sela-sela proses pembelajaran berlangsung didalam kelas. Selain itu keteladanan dari guru merupakan salah satu kunci kesuksesan untuk menanamkan sebuah karakter pada diri peserta didik. Keteladanan memang cara yang efektif dalam mengingatkan dan mengajarkan siswa karena dalam masa perkembangan yang dialami siswa diperlukan sosok yang menjadi panutan terutama seseorang yang berada di sekeliling siswa.

\section{Pendidikan Karakter Religius di SD Kreatif}

Sikap religius merupakan landasan hidup yang penting dalam bertingkah laku menurut kepercayaan kepada Allah SWT dan diperlukan dalam membentuk kepribadian seseorang yang taat kepada seluruh ajaran Allah SWT. Untuk itu dalam membentuk kepribadian siswa diperlukan penanaman sikap religius terutama pada sekolah yang berlandaskan keislaman. Dalam sekolah yang bersaskan agama, sikap religius merupakan dasar atau ruh dari setiap proses pembelajaran. Segala sesuatu yang dilakukan siswa harus didasarkan pada sikap religius yang bertujuan untuk membentuk siswa yang berakhlak mulia.

Dalam tataran nilai, budaya religius berupa semangat berkorban, semangat persaudaraan, semangat saling menolong dan tradisi mulia lainnya. Sedangkan dalam tataran perilaku, budaya religius berupa tradisi shalat berjamaah, gemar bersedekah, rajin belajar dan perilaku mulia lainnya. Dengan demikian, budaya religius sekolah pada hakikatnya adalah terwujudnya nilai-nilai ajaran agama sebagai tradisi dalam berperilaku dan budaya organisasi yang diikuti oleh seluruh warga sekolah. Dengan menjadikan agama sebagai tradisi dalam sekolah, maka secara sadar maupun tidak 
Eries, Manajemen Pembelajaran Pendidikan Karakter...

ketika warga sekolah mengikuti tradisi yang telah tertanam tersebut, sebenarnya warga sekolah sudah melakukan ajaran agama.

\section{Pelaksanaan Pendidikan Karakter di SD Kreatif Pendidikan Karakter Kedisiplinan di SD Kreatif}

Pelaksanaan menanamkan pendidikan karakter kedisiplinan kepada peserta didik diterapkan ketika proses pembelajaran di kelas maupun diluar kegiatan pembelajaran. Peserta didik diwajibkan untuk memakai seragam yang rapi dan mematuhi aturan yang ada pada sekolah. Apabila peserta didik melanggar tata tertib yang berlaku, maka peserta didik mendapatkan teguran dari guru agar ia tidak melanggar tata tertib lagi. SD Kreatif juga menerapkan pendidikan karakter kedisiplinan yaitu dengan cara datang tepat waktu ke sekolah. Semua peserta didik sudah ada di dalam kelas ketika bel masuk berbunyi. Dengan ditanamkan kedisiplinan kepada peserta didik yaitu datang tepat waktu, maka proses pembelajaran akan berjalan dengan lancar.

Pendidikan karakter kejujuran dan beribadah juga termasuk kedalam penanaman pendidikan karakter kedisiplinan yang diterapkan oleh SD Kreatif kepada peserta didik. Peserta didik dilatih untuk bersikap jujur baik sesama teman, dengan guru, maupun warga sekolah yang lain. Peserta didik juga harus bersikap jujur ketika proses pembelajaran berlangsung. Misalnya tidak menyontek ketika melaksanakan ujian maupun ulangan harian. Ketika diluar proses pembelajaran, peserta didik harus menanmkan sikap jujur baik dilingkungan sekolah, keluarga, maupun masyarakat, yaitu berkata sesuai dengan apa yang telah dilakukan dan diketahuinya. Selain bersikap jujur, peserta juga harus disiplin dalam beribadah. Peserta didik membaca asmaul husna sebelum belajar, melaksanakan sholat dhuha, dan sholat dhuhur secara berjamaah di sekolah. Mulai sejak dini peserta didik dilatih untuk menanamkan pendidikan karakter disiplin dalam beribadah agar ia mempunyai sifat religius dalam dirinya. Tanpa harus dipaksa oleh guru, peserta didik dengan disiplin melakukan hal tersebut yang sudah menjadi kebiasaan sehari-hari peserta didik .

\section{Pendidikan Karakter Kejujuran di SD Kreatif}

Pihak SD Kreatif menanamkan pendidikan karakter kejujuran kepada peserta didik melalui pelaksanaan program kantin kejujuran. Peserta didik mengambil barang apa saja sesuai kebutuhannya dengan meletakkan uang sesuai harga barang yang diambil pada tempat yang telah disediakan oleh guru. Dari program kantin kejujuran, guru mengetahui bahwa peserta didiknya jujur ataupun sebaliknya. Guru menghitung jumlah barang dan jumlah uang yang diterima dari hasil penjualan barang maupun snack pada kantin kejujuran. Jika hasil penghitungan sesuai dengan kenyataan yang ada, maka peserta didik jujur dalam mengambil barang dan meletakkan uang sesuai harga barang yang diambil. Jika penghitungan tidak sesuai dengan kenyataan, maka guru perlu mengevaluasi apakah uang tersebut jatuh, terselip, atau ada peserta didik yang belum jujur. Apabila ada kejadian seperti itu, maka guru memberi nasehat dan motivasi 
Eries, Manajemen Pembelajaran Pendidikan Karakter...

kepada peserta didik agar bersikap jujur dalam segala hal. Karena dengan mempunyai sikap jujur sejak dini, maka akan memberikan pengaruh yang baik pula dikehidupan yang akan datang.

Selain itu, terdapat pula proses yang menerapkan piket peserta didik untuk mengambilkan jatah makanan teman-temannya sekelas dengan jatah yang telah diberikan oleh pengelola dapur dan wajib mengembalikan sisa jatah makan temannya apabila terdapat kelebihan. Piket yang diterapkan SD Kreatif yaitu secara bergilir, peserta didik mendapatkan jadwal masing-masing. Peserta didik wajib melaksanakan piker tersebut sesuai dengan hari yang sudah ditentukan secara bergantian dan bergilir disetiap harinya. Peserta didik harus jujur dan bertanggungjawab dalam melaksanakan piket. Apabila ada sisa dari jatah yang diberikan, maka harus dikembalikan ke dapur. Dari kegiatan itu, peserta didik dilatih mempunyai sikap jujur sejak dini agar menjadi kebiasaan yang baik dalam kehidupan sehari-hari baik di sekolah, keluarga, maupun masyarakat.

\section{Pendidikan Karakter Religius di SD Kreatif}

Peserta didik SD Kreatif tidak hanya belajar berkenaan kognitif saja, melainkan juga belajar dan dilatih mengenai penanaman pendidikan karakter religius pada proses pembelajaran maupun diluar proses pembelajaran. Pendidikan karakter religius tersebut diantaranya yaitu mengucapkan salam ketika memasuki kelas maupun ruang guru, membaca asmaul husna sebelum melakukan kegiatan pembelajaran, melaksanakan sholat dhuha, melaksanakan sholat duhur secara berjamaah.

Peserta didik dilatih untuk mengucapkan salam ketika memasuki ruangan agar menjaga sopan santun dan belajar menanamkan sikap religius dalam diri peserta didik. seperti halnya berdoa sebelum belajar, peserta didik membaca asmaul husna secara bersama-sama yang dibimbing oleh guru sebelum melaksanakan kegiatan pembelajaran. Peserta didik senantiasa membaca asmaul husna dengan sungguh-sungguh agar ilmu yang didapat itu bermanfaat bagi dirinya maupun orang lain. pada jam istirahat, selain peserta didik berkunjung ke kantin kejujuran, ia juga pergi ke mushola untuk membiasakan diri sholat dhuha. Sholat dhuha dilakukan secara individu, namun semua peserta didik dilatih untuk membiasakan sholat dhuha di mushola sekolah. Selain sholat dhuha, peserta didik juga melaksanakan sholat dhuhur berjamaah dengan warga sekolah yang lainnya. Sholat dhuhur dilaksanakan oleh peserta didik kelas tinggi yang pulang sekolahnya diatas pukul 12.00. Bagi peserta didik kelas rendah yang jam pulang sekolahnya sebelum pukul 12.00 maka diperbolehkan untuk pulang terlebih dahulu dan melaksanakan sholat dhuhur di rumah.

\section{Evaluasi Pendidikan Karakter di SD Kreatif}

Dalam hal penilaian pendidikan karakter, belum tersedia instrumen yang dapat digunakan secara tepat. Untuk itu perlu dikembangkan instrumen penilaian pendidikan karakter dalm pembelajaran di Sekolah Dasar sesuai dengan karakteristik anak usia SD. 
Eries, Manajemen Pembelajaran Pendidikan Karakter...

Dengan dikembangkannya instrumen penilaian pendidikan karakter dalam pembelajaran di SD akan dapat memudahkan guru SD dalam melaksanakan penilaian pembelajaran dalam rangka pendidikan karakter dan pada gilirannya implementasi pendidikan karakter bagi peserta didik SD dapat berlangsung guna mendukung terwujudnya tujuan pendidikan nasional.

Pendidikan karakter tidak perlu menjadi suatu mata pelajaran tersendiri. Pendidikan karakter dapat diintegrasikan dalam pembelajaran pada setiap mata pelajaran. Materi pembelajaran yang berkaitan dengan norma atau nilai-nilai pada setiap mata pelajaran perlu dikembangkan, dikaitkan dengan konteks kehidupan sehari-hari. Dengan demikian, pembelajaran nilai-nilai karakter tidak hanya pada tataran kognitif, tapi menyentuh pada pengalaman nyata dalam kehidupan sehari-hari peserta didik di masyarakat. Untuk mengetahui keberhasiloan dalam pembelajaran penanaman nilainilai karakter diperlukan instrumen penilaian yang sesuai dengan tujuannya, dengan cara membandingkan perilaku anak dengan indikator karakter yang ditetapkan.

\section{Upaya SD Kreatif untuk Mengadakan Perbaikan Pembelajaran Pendidikan Karakter Peserta Didik}

Peran guru sebagai pendidik merupakan oeran-peran yang berkaitan dengan tugas-tugas memberi bantuan dan dorongan, tugas-tugas pengawasan dan pembinaan, serta tugas-tugas yang berkaitan dengan mendisiplinkan peserta didik agar menjadi patuh terhadap aturan-aturan sekolah dan norma hidup dalam keluarga dan masyarakat. Upaya SD Kreatif untuk memperbaiki pendidikan karakter peserta didik yaitu yang paling utama seorang pendidik memberi contoh yang baik kepeda peserta didik, karena peserta didik akan meniru perilaku dari orang yang ada disekitarnya. Guru ketika mengajar dan mendidik peserta didik baik didalam kelas maupun diluar kelas harus sanggup menunjukkan kewibawaan atau otoritasnya. Artinya, ia harus mampu mengendalikan, mengatur, dan mengontrol kelakuan peserta didik. Kewibawaan seorang guru dapat menegakkan disiplin demi kelancaran dan ketertiban proses belajarmengajar untu pembentukan karakter peserta didik.

Pendidikan karakter yang ditanamkan kepada peserta didik sejak usia dini merupakan upaya yang harus melibatkan semua pihak, baik dari lingkungan keluarga, lingkungan sekolah, dan masyarakat. Membangun karakter peserta didik tidak hanya dilakukan di sekolah saja, namun perlu adanya bimbingan dari keluarga yang merupakan pendidikan pertama peserta didik. Keluarga yang mendidik anaknya dengan baik, maka pendidikan karakter juga sudah tertanam pada diri peserta didik. Lingkungan sekolah dan masyarakat merupakan faktor pendukung dalam pembentukan karakter peserta didik.

SD Kreatif mempunyai program penanaman pendidikan karakter kepada peserta didik yang bertujuan agar peserta didik mampu menjadi sosok pribadi dan etika yang baik di lingkungan keluarga, sekolah, dan masyarakat. Tidak hanya peserta didiknya 
Eries, Manajemen Pembelajaran Pendidikan Karakter...

saja yang harus belajar membangun pendidikan karakter dalam dirinya, namun pendidik di SD Kreatif juga memberi contoh perbuatan dan kebiasaan yang baik sesuai dengan pendidikan karakter yang sudah terprogram pada visi dan misi SD Kreatif. Penanaman pendidikan karakter dapat dilakukan ketika proses pembelajaran yang dimasukkan pada materi pembelajaran, maupun ketika diluar proses pembelajaran. Guru mengajarkan bagaimana sopan santun kepada sesama teman, kepada guru, kepada kepala sekolah, warga sekolah yang lain, serta menanamkan pendidikan karakter sesuai dengan program dari SD Kreatif.

\section{SIMPULAN}

Pendidikan karakter peserta didik diperlukan untuk membangun akhlak yang mulia tidak hanya di dalam lingkungan sekolah namun juga di lingkungan keluarga maupun masyarakat dengan proses pendidikan yang melibatkan aspek kognitif, afektif, dan psikomotor. Pendidikan karakter yang direncanakan dan diterapkan oleh SD Kreatif ada 3, yaitu pendidikan karakter kedisiplinan, kejujuran, dan religius. Peserta didik dilatih untuk berperilaku disiplin waktu, kerapian, kejujuran, dan disiplin dalam beribadah. Kejujuran pada peserta didik juga ditanamkan sejak dini melalui program kantin kejujuran dan pembagian piket untuk mengambilkan snack/makanan kepadan teman-temannya. Tidak hanya itu, peserta didik tidak melupakan nilai-nilai religi yang harus dibangun pada dirinya. Pendidikan karakter religius tercermin ketika peserta didik mengucapkan salam ketika memasuki ruangan, membaca asmaul husna sebelum proses belajar mengajar, melaksanakan sholah dhuha, dan melaksanakan sholat dhuhur berjamaah. Pendidikan karakter yang diterapkan di SD Kreatif tidak hanya dilaksanakan dalam proses pembelajaran, melainkan juga dilaksanakan di luar proses pembelajaran. Pendidik tidak hanya meminta peserta didiknya untuk melatih dan menanamkan pendidikan karakter dalam dirinya. Pendidik juga memberi contoh perilaku yang sesuai dengan pendidikan karakter yang telah direncanakan dan diterapkan pada SD Kreatif.

\section{SARAN}

1. Peserta didik harus dikenalkan dan ditanamkan pendidikan karakter yang baik sejak dini mulai dari lingkungan keluarga, karena keluarga merupakan pendidikan yang pertama dan utama.

2. Pendidik yang memberi contoh perbuatan yang baik akan ditiru oleh peserta didiknya karena pendidik memiliki peranan yang penting dalam membangun karakter peserta didik.

3. Pendidikan karakter sebaiknya ditanamkan disegala situasi, tidak hanya pada proses belajar mengajar saja, melainkan juga diajarkan pada lingkungan peserta didik.

4. Pendidikan karakter merupakan upaya yang harus melibatkan semua pihak baik di lingkungan keluarga, sekolah, dan masyarakat. 
Eries, Manajemen Pembelajaran Pendidikan Karakter...

\section{DAFTAR RUJUKAN}

Akbar, Sa'dun. 2010. Pengembangan Model-model Pendidikan Karaker Berbasis Nilainilai Kehidupan di Jawa Timur, fokus Uji Coba Model Skala Terbatas. Penelitian Mandiri. Malang: UM

Akbar, Sa'dun. 2011. Revitalisasi Pendidikan Karakter di Sekolah Dasar, Teks Pidato Pengukuhan Guru Besar dalam bidang Ilmu Pendidikan/Pendidikan Dasar. 8 Juni, Malang:UM

Aqip, Zainal dan Sujak. 2011. Panduan dan Aplikasi Pendidikan Karakter. Bandung: Yrama Widya

Pedoman Pelaksanaan Pendidikan Karakter. 2011. Pusat Kurikulum dan Perbukuan. (Online), (http://gurupembaharu.com), diakses 5 Maret 2016)

Pengembangan Pendidikan Budaya dan Karakter Bangsa. 2010. Pusat Kurikulum dan Perbukuan. (Online), (http: //tendik.kemendiknas.go.id), diakses 5 Maret 2016八

Satori, Djam'an dan Komariah, Aan. 2010. Metodologi Penelitian Kualitatif. Bandung: Alfabeta

Sugiyono. 2007. Memahami Penelitian Kualitatif. Bandung: Alfabeta

Yuniarti, Lusi. 2011. Profil Pelaksanaan Pembelajaran di Kelas 1 Sekolah Dasar Negeri Percobaan Malang. Skripsi tidak diterbitkan. Malang: PPs UM. 